\title{
24. Karyological Studies of Two Species of the Japanese Coccinellid Beetles, Harmonia axyridis Pallas and Menochilus sexmaculatus (Fabr.)
}

\author{
By Hidehiro HoshibA*) and Keiko NiIJIma**) \\ (Communicated by Sajiro Makino, M. J. A., March 12, 1987)
}

Takenouchi (1976) reported 16 in the chromosome number on a spermatogonium cell of $H$. axyridis. These chromosomes consisted of 14 autosomes and a pair of the sex chromosomes $\left(\mathrm{X}_{\mathrm{p}}\right)$. $\mathrm{X}_{\mathrm{p}}$ was the most wide spread system in the Coleoptera, indicating a relatively large metacentrix $\mathrm{X}$ and an extremely smaller metacentric $\mathrm{Y}$.

Twenty chromosomes were observed in the male of $M$. sexmaculatus from Indian species by Yadav and Pillai (1979). These consisted of 18 submeta or acrocentric autosomes with acrocentric $\mathrm{X}$ and spherical $\mathrm{y}\left(\mathrm{Xy}_{\mathrm{p}}\right)$.

The method of successive rearing of the aphidophagous coccinellid beetles in an incubator has been established by Okada et al. (1971). Since then, we have been interested in the cytological studies of these beetles.

Karyogram analyses of the two species of the aphidophagous coccinellid beetles are presented in this paper.

Materials and method. The two species of coccinellid beetles were collected in May to July of 1986 at Machida-shi, Tokyo. They were successively reared by means of the powdered drone (honeybee larvae) as described by Okada et al. (1971).

The 3rd to the last instar larvae of both sexes were dissected and taken out the reproductive organs when they were on gonium (somatic) divisions. These organs were pretreated in the $0.5 \% \mathrm{KCl}$ solution for $30 \mathrm{~min}$. Preparations were made by the usual air drying method, and stained by the Giemsa solution at $\mathrm{pH} 6.8$ for $30 \mathrm{~min}$.

Results and discussion. 1) Harmonia axyridis Pallas. Chromosome number was $2 n=16\left(14 \mathrm{AA}+\mathrm{XX}\right.$ in the female and $14 \mathrm{AA}+\mathrm{Xy}_{\mathrm{p}}$ in the male). The autosomes consisted of a pair of the large metacentric with a secondary constriction), others were moderately large 5 pairs of the metacentric and a pair of the submetacentric chromosomes. The $\mathrm{X}$ was moderately large submetacentric and $y_{p}$ was small metacentric chromosome (Fig. 1, a, b). In the metaphase of female cells, one of the $\mathrm{X}$ chromosomes usually elongated at the shorter arm, this may related to the sex determining mechanism of this species.

2) Menochilus sexmaculatus (Fabr.). Chromosome number was $2 n=20$ $\left(18 \mathrm{AA}+\mathrm{XX}\right.$ in the female and $18 \mathrm{AA}+\mathrm{Xy}_{\mathrm{p}}$ in the male). A first pair of the autosomes were moderately large submetacentric chromosomes and the other autosomes were 6 pairs of moderately large metacentric, and two pairs of the small metacentric chromosomes. The $\mathrm{X}$ chromosome belonged to the small metacentric group, $\mathrm{y}_{\mathrm{p}}$ was the extremely small metacentric chromosome (Fig. 2, a, b).

\footnotetext{
*) Daito Bunka University, Dai-ichi High School, Itabashi, Tokyo.

**) Laboratory of Entomology, Faculty of Agriculture, Tamagawa University, Tokyo.
} 


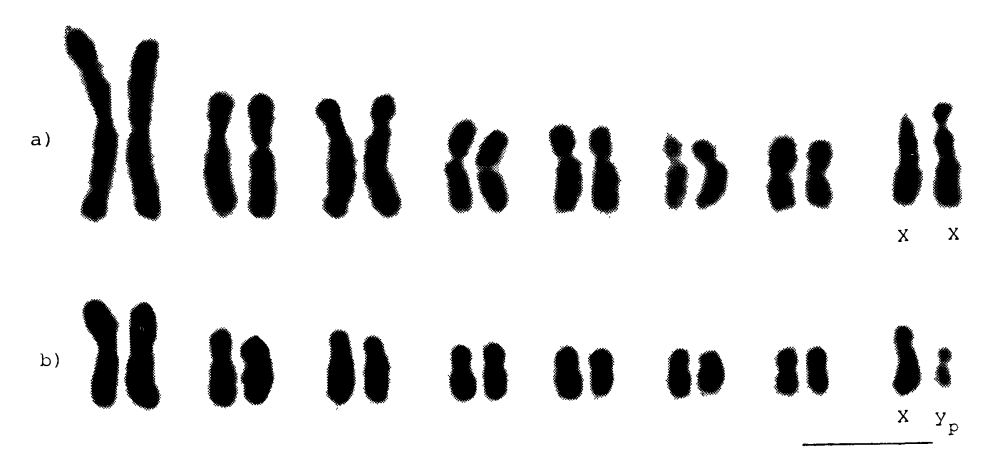

Fig. 1. Karyograms of Harmonia axyridis Pallas (A, female and B, male). $2 n=16\left(14 \mathrm{AA}+\mathrm{XX}\right.$ 우 and $\left.14 \mathrm{AA}+\mathrm{Xy}_{\mathrm{p}} \hat{\mathrm{o}}\right) . \quad$ Bar indicates $5 \mu$.

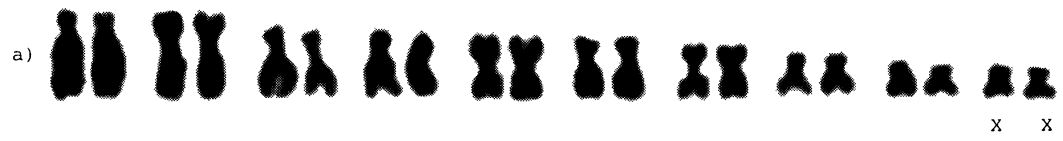 $886683682838228280 \times:$}

Fig. 2. Karyograms of Menochilus sexmaculatus (Fabr.) (A, female and B, male). $2 n=20\left(18 \mathrm{AA}+\mathrm{XX}\right.$ 우 and $18 \mathrm{AA}+\mathrm{Xy}_{\mathrm{p}}$ 令). Bar indicates $5 \mu$.

Thus, our observations (on the Japanese species) did not agree with those of Yadav and Pillai (1979, on the Indian species). In this species, the large metacentric chromosomes (with the distinct secondary constriction) and the $\mathrm{X}$ chromosome elongation as found in $H$. axyridis were not observed.

Acknowledgments. We are thankful to Professor Emeritus, Dr. S. Makino, M. J. A., of the Hokkaido University for reading through this manuscript. We are also indebted to Professor Emeritus, Dr. I. Okada of the Tamagawa University and Professor, Dr. S. Sakai of the Daito Bunka University.

\section{References}

Okada, I., Matsuka, M., and Hoshiba, H.: Apiacta, 6, 119-120 (1971).

Takenouchi, Y.: Proc. Japan Acad., 52B, 62-65 (1976).

Yadav, J. S., and Pillai, R. K.: Nucleus, 22, 104-109 (1979). 